\title{
ENTREPRENEURSHIP IN THE INDUSTRY OF TOURISM
}

\author{
Ciprian-Constantin Pătrăuceanu ${ }^{1}$, Oleg Petelca ${ }^{2}$ \\ 1 University of Oradea, Romania \\ ${ }^{2}$ Alexandru loan Cuza University of Iași, Romania \\ patrauceanuc@yahoo.com \\ oleg.petelca@gmail.com
}

"All human beings are inherently entrepreneurial, that is, entrepreneurial potential is in all of us, in the same sense that all humans are innately musical, linguistic and morally reflective." (World Economic Forum)

\begin{abstract}
In the economic field, entrepreneurship is important because it brings a contribution to the economic and social development; it is also mentioned in certain scientific works within the field, thus constituting a generator of innovation and of the capacity of coping with competition. Entrepreneurship may represent the engine of an economy, by bringing along a particular dynamism in economy. The current entrepreneurial reason may be categorised as the most negative period of its history. Tourism represents a system of interests through which a person may occupy their free time, comprising various journeys to different far-away destinations. This industry was founded in order to meet the asset and service demands of tourists once they get to their destination, at certain standards of quality. The size and evolution of national tourism may be influenced by certain relations on the international tourist market, by the orientation of diverse tourist flows, and by a certain degree of worldwide competition.
\end{abstract}

Keywords: entrepreneurship; tourism; innovation; business; industry.

JEL Classification: $A 10 ; Z 32$.

\section{Introduction}

Most of the times, "promoting youth entrepreneurship is considered a way to combat the effects of the recent financial crisis and to create new jobs" (Anton, 2018: 9). Entrepreneurs may represent "individuals who think and act in order to transform the ideas into commercial opportunities and to create value" (Leach, 2012: 7) and they may be those persons (business owners) seeking to generate value by creating or extending an economic activity, by identifying and exploiting new products, processes or markets (OECD, 2009: 6). According to Professor Howard Stevenson, entrepreneurship may be considered "the pursuit of opportunity beyond resources controlled" (Stevenson et al.,1990). Entrepreneurship may also represent "an activity that involves the discovery, evaluation and exploitation of opportunities to introduce new goods and services, ways of organizing, markets, processes" (Shane,2000:217-226). A challenge faced by any entrepreneur is related to the management of the entrepreneurial process, with the main core in terms of management of innovation (Bădulescu, 2014:24). In order to build a successful business, it takes a great deal of courage and patience; few people have such qualities. For success in the entrepreneurial endeavour, an entrepreneur must - first of all - be intelligent and committed. Entrepreneurs also need a very good management team and, not least, an excellent outlet.

Entrepreneurship emerged from time immemorial: entrepreneurs are those who - by innovation and by their activity of business development - transform the static circular stream of economic flows into a dynamic one (Ghenea,2011).

Due to the two tourism sectors - accommodation and meal - we are made aware that the hospitality industry may be more prone to risk than other industries. 


\section{Touristic financing}

The pandemic has really challenged the European tourist market; given all the restrictions, it stopped in the first months of the year 2020, at both European and global level. OECD argues that the decline of activities reaches around $70 \%$, largely depending on the health crisis and its resolution. Most tourist enterprises have had to deal with a severe cash crisis; according to estimates, losses in the European Union for hotels, tour operators and railway raises to $85 \%$; for airlines to $90 \%$. Reservations made for tourism in the EU decreased by $90 \%$ compared to the previous years. The crises hit the SMEs hard; they fought to avoid bankruptcy and turning their employees into unemployed persons; due to the lack of funding, they may end up in this situation. The crisis may have a negative impact in Europe, with the loss of around six million jobs, without any support for the labour force. Some states have adopted aiding measures, by providing various grants (up to EUR 800,000), loans, and various damages paid to enterprises for most losses suffered because of this pandemic. The European Union, in order to help most SMEs - mostly those within the tourism sector unlocked a fund of around 1 billion EUR, accounting for a guarantee for the so-called European Investment Fund, by mobilizing a guarantee for the loan of 8 billion EUR, an amount necessary for the economic relaunch. The SMEs in the field of tourism may cover varus costs concerning labour force, diverse stocks and expenses within the funding of circulating capital. The cohesion policy within territorial strategies should help the most affected areas by the crisis, by developing various objectives for supporting the various tourist enterprises and by relaunching operations through more accessible funding, this combining it with different measures of digitisation and investments in competences, through various regional European funds, by promoting sustainable and mobility tourism. Those strategies must focus the cohesion funds towards various investments in order to restore the tourists' feeling of security (i.e., safe management of health protocols and management of green areas).

Most creditors argue that the various accommodation and meal practices do not highlight a general risk concerning the tourist activities. The industry of tourism comprises several sectors, covering a small part of certain ongoing businesses.

Tourism is an income source for most areas, thus contributing to an economic diversification and to the consolidation of certain companies carrying out their activity in their respective field. Financing from the European Union structural funds may be of great assistance to the smaller tourist enterprises, bringing them a certain degree of modernisation, renovation, and extension of the accommodation spaces. Hence, they may become more qualitative, which makes them more profitable and reliable. The participation in certain marketing courses for entrepreneurs may be very useful, thus adding value to the tourist field.

Tourism may become an important part of the global economy, thus supporting economic growth in certain countries, generating jobs. The tax and foreign currency income may lead to an improvement of people's quality of life.

Tourist consumption may entail various expenses made by tourists, thus representing tourist demand in order to provide various tourist motivational services (Lanquar,1987:30). Certain policies in the marketing field may be influenced by the synchronism between production and consumption.

The field of tourism may also be a services sector; a feature specific to it is thus that "the volume of consumption equates with the volume of production, which means that one can only produce what one consumes" (Cosmescu, 1998: 100).

A volume in what concerns tourist consumption may be staged, depending on the price of certain tourist products, and from the perspective of the consumers' income. Professor Krapf (1964) stated at the beginnings of tourism development: "Tourism is a typical example of satisfying needs that correspond to the views formulated regarding the closest lifestyle to the standing of each individual. Hence, it is not derived exclusively from utilitarian reasons, 
but it also contains - to a high extent - extra-economic thus irrational elements" (Kraph, 1964: 63).

There are several important theories of tourism development that analyze the evolution of tourism and are based on the life cycle of travel (Butler, 1980) (Butler \& Miossec, 1993). These theories describe the development of tourism in a cyclical pattern. According to these theories, changes in the tourism market take place not for economic or social reasons, but because of the changing nature of the tourism market and the constantly changing tourism motivations. Some authors characterize the development of tourism through the stages of increasing the number of tourists. Thus, according to evolutionary theories of tourism development, the development of rural tourism can be seen as a natural process of change. A correct understanding of this process provides a better understanding of the dynamism of rural tourism development and allows the identification of the main factors that have an impact on changes in rural tourism, as well as for the selection of appropriate methods for their identification and evaluation.

Turner (2005) identified three stages of tourism development in a given area: finding the right area for tourism development; the rapid development of tourism in this area; strengthening tourism in the area. Initially, tourism is developing slowly. When the right location is discovered and popularized, tourists begin to invade this area, and the local community refuses other economic activities and begins to build infrastructure for tourists and provide the required services. If tourism continues to evolve, it reaches the last stage of tourism development and becomes fully mature. It becomes a formal activity, which is based on local resources, facilities and attractive services. The promotion of tourism development is carried out by tourism companies. When tourism becomes a regulated activity, significant changes in the social, cultural and natural environment become inevitable. The model developed by Turner can be applied in a completely new area for the development of tourist infrastructure. The disadvantage of this model is the focus on changes in the territory, and the motivations of tourists and local communities are not assessed (Turner, 2005).

Lopa and Marecki (1999) propose to characterize the development of tourism by using the following relevant periods: the period in which the number of tourists is constantly growing; the period in which the number of tourists reaches a maximum; the period in which the number of tourists stabilizes; the period in which the number of visitors decreases. This cycle of tourism development can be described as the impact of the number of tourists on the result. When tourism development is not yet at a high level, the area usually attracts lowincome tourists, who tend to spend less and stay in cheap accommodation or tents. These tourists are mainly interested in the attractiveness of the area, but are not interested in tourist services. As the tourism industry grows and service offerings expand, higher-income tourists come to the area using more expensive tourism services and products. Such tourists need high quality services and modern hotels to be built. These needs of tourists lead to the need for investment in the area. High-income tourists are gradually replacing those who are not attracted to the variety of entertainment and tourist infrastructure. Mass tourism promotes the integration of transport infrastructure, airports, high quality roads, railways, water transport. Over a period of time, mass tourism has gradually replaced high-income tourists with middle-income and low-income tourists. It is possible to distinguish the following groups of tourism consumers: fascinated individual tourists, high-income and demanding tourists, representatives of mass tourism. It should be noted that in some tourist regions, the development of tourism may not have all the stages and may be irregular. The expansion of tourism and various marketing tools aimed at promoting all user groups in the area is a complex process, with no clearly predictable results (La Lopa \& Marecki, 1999).

The most well-known and widely accepted cyclical theory of tourism development was developed by Butler. Butler's cyclic model includes 4 stages: exploration, involvement, development and in the fourth stage, saturation is reached and four variants of evolution are possible: decline, invigoration, stagnation or consolidation. 
(1) Exploration. The town is discovered by people who appreciate its beauty and culture. Tourists arrive in small numbers and bear all the shortcomings: few facilities, low accessibility.

(2) Involvement. The number of tourists is small, but growing, the flow of tourists tends to occur. Tourists encourage local companies to start offering tourist services and selling goods to travelers. The destination is becoming more and more known, increasing its accessibility and promotion.

(3) Development. The period of dynamic growth. The flow of tourists is growing rapidly. The additional investments reduce the services in close connection with the natural elements of the business.

(4) In the fourth stage, saturation is reached and four variants of evolution are possible: decline, invigoration, stagnation or consolidation. (4.1) Decline. If the destination does not respond to social, economic, political or environmental problems, the number of tourists begins to decline sharply, because they prefer more attractive locations. The cycle can enter the regeneration phase if there have been significant changes in the resources used. (4.2) Regeneration. In this phase of the cyclical model, the number of tourists is constantly increasing, but may increase or decrease rapidly. At this stage, an opportunity arises to move on to the next cycle. (4.3) Stagnation. The number of tourists arriving is stabilizing. This results in economic, social, political and environmental problems. The development of the tourism industry significantly affects the qualitative characteristics of the area, which were considered as the main factors of attraction and exclusivity at the beginning of the tourist cycle. This stage can take a short or very long time. (4.4) Consolidation. The number of tourists is constantly growing. Marketing tools are used to extend the tourist season to attract more tourists (Butler, 1980).

The theories of tourism development developed by Butler, Miossec, Turner, Lopa, Marecki are based on the stages of tourism development. Theories of tourism development have largely focused on the needs and behavior of tourists. The behavior of tourists remains among the most researched areas in marketing and tourism (Cohen, Prayag, \& Moital, 2014). There are a number of studies that try to determine the difference in perception depending on the characteristics of the consumer. Research by $\mathrm{Li}$, Li and Hudson (2013) has shown that different generations have different preferences when choosing tourist destinations, when choosing activities to travel and when choosing sources of travel information, but important similarities have also been highlighted. Both Baby Boomers and Generation X consider online sources of travel information more important than Generation $Y$. At the same time, the Baby Boomers generation relies heavily on online sources of information that support the work of Beldona et al. (2009), which found that the use of the Internet has increased substantially for the Baby Boomers generation compared to other generations. (Li, Li, \& Hudson, 2013). Research by Serban Pelau, \& Chinie (2017) has also shown that the biggest differences in age dependence are in the choice of leisure activities and the use of modern electronic equipment. (Serban, Pelau, \& Chinie, 2017). A number of researchers (Fyall, Leask, Barron, \& Ladkin, 2017; Losada, Alen, Dominquez, \& Nicolau, 2016) have also shown that differences between generations also play an important role in the choice of tourism products. The influence of the gender of the consumer of tourist services and the behavior of the tourist has also been shown by a number of researchers (Pelau \& Chinie, 2018; Legoherel, Hsu, \& Dauce, 2015; Tkaczynski, Rundle-Thiele, \& Beaumont, 2009; Nistoreanu, Pelau, Ene, \& Lazăr, 2018). Research conducted by Eusebio and others has shown the link between motivations for tourism and the profile of the rural tourism consumer, as well as its influence on the choice of activities during travel in a rural area (Eusebio et al., 2017). The results of research conducted by Park and Yoon (2009) suggest that consumers of tourism can be divided into four segments based on the motivations of tourists. The profiles of these four segments showed significant differences in socio-economic characteristics, holiday behavior and activity preferences (Park \& Yoon, 
2009). Knowing this information can help tourism companies develop products and services in accordance with consumer wishes.

The tourist ecosystem of the entire Europe may cover a wide array of various activities such as accommodation, travels, recreation, culture, etc, thus contributing by $10 \%$ to the GDP of the European Union, which makes it one of the main tourist destinations worldwide, it recorded approximately 563 million arrivals and about 30\% of the global incomes in 2018 (UNWTO).

Tourism may represent for most Member-States of the European Union a major contribution to the economic and social system, thus providing both jobs and gratifying incomes, but the ecosystem in question is seriously affected. Therefore, World Tourism Organisation (UNWTO) predicts a dramatic drop of international tourism, even by $80 \%$, thus accounting for losses up to 1,100 billion Euros, in terms of global exports. Actually, most residents of the European Union take 385 million trips, thus spending around 190 billion Euros (Eurostat, 2019). European tourism depends for the most part on the European residents having free access to the entire territory of the European Union. Artificial intelligence and robotics may bring their contribution to the monitoring of social distancing - pursuant to data protection legislation - and to the disinfection of the places periodically visited by tourists.

\section{Conclusion}

The end of restrictions may provide Europeans with vast opportunities to travel nationally and internationally, thus discovering new experiences. Many European cities focused on cultural tourism. Regions and cities may be sometimes responsible from the perspective of tourism and transportation policy; if they are applied without previous coordination, they may neutralise or obstruct one another. Europe must remain the top destination in international tourism, being characterised by innovation sustainability and value. Digital transition may be an important battle won for tourism, because it may provide new method for managing tourist flows and opportunities. Digital tools may consolidate people's trust that they can rely on their travel. This entails investments in cybernetic security, digital innovation and connection of tourist businesses.

The European Commission may support most local businesses from this branch of tourism, through certain digital innovation centres, thus helping them get through the tourist season successfully, with the use of cleaning robots, of population management, of an intelligent booking system, (a "hackathon" for certain digital technologies within the industry of tourism).

\section{References}

Anton, S.G., Aghiorghiesei, D.T., Maha, L.G., Onofrei, M., Antreprenoriat. Înființarea,finanțarea și managementul noilor afacer, Ed.Universității "Alexandru loan Cuza" Iași, 2018,

Bădulescu, D., Bădulescu, A., Antreprenoriatul : cum, cine, când? Cluj-Napoca: Presa Universitară Clujeană, 2014

Bădulescu, D., Dezvoltarea și finanțarea afacerilor antreprenoriale. Particularități în turism, ClujNapoca, Presa Universitară Clujeană, 2013

Butler, R., (1980). The Concept of a Tourist Area Cycle of Evolution: Implications for Management of Resources, Canadian Geographer, Vol. 24, Nr. 1, pp. 5-12.

Butler, R., Miossec, J., (1993). Strategic investment decisions: theory, practice and process, London, New York.

Cohen, J., Prayag, G., \& Moital, M. (2014). Consumer behaviour in tourism: Concepts, influences and opportunities. Current Issues in Tourism, 17(10), 872-909.

Cosmescu, I. - Turismul, fenomen complex contemporan, Ed. Economică, București, 1998,

Eurostat - Sosiri în structurile de primire turistică - date lunare ( 2019 )

Eusebio, C., Carneiro, M., Kastenholz, E., Figueiredo, E., \& Silva, D. (2017). Who is consuming the countryside? An activity-based segmentation analysis of the domestic rural tourism market in Portugal. Journal of Hospitality and Tourism Management, 31, 197-210. 
Fyall, A., Leask, A., Barron, P., \& Ladkin, A. (2017). Managing Asian attractions, Generation Y and face. Journal of Hospitality and Tourism Management, 35-44.

Ghenea,M., Antreprenoriat .Drumul de la idei către oportunități și success în afaceri, Ed.Universul Juridic, București, 2011.

Krapf, K - La consummation touristique, Aix-en-Provence, 1964,

La Lopa, J. M., Marecki, R. F., (1999). The critical role of quality in the tourism system, ProQuest Science Journals, nr. 8, pp. 37-42.

Lanquar, R - L'Economie du tourisme, Presses Universitaires de France, Paris, 1987,

Leach, C.,Melicher, R., Entrepreneurial Finance, $4^{\text {th }}$ ed.,South Western Cengage Learning, Mason, 2012

Legoherel, P., Hsu, C., \& Dauce, B. (2015). Variety-seeking: Using the CHAID segmentation approach in analyzing the international traveler market. Tourism Management, 46, 359-366.

$\mathrm{Li}, \mathrm{X}$., Li, X., \& Hudson, S. (2013). The application of generational theory to tourism consumer behavior: An American perspective. Tourism Management, 37, 147-164.

Losada, N., Alen, E., Dominquez, T., \& Nicolau, J. (2016). Travel frequency of seniors tourists. Tourism Management, 88-95.

Nedelea, Al., - Piața turistică , București , Editura Didactică și Pedagogică , 2003

Nistoreanu, P., Pelau, C., Ene, I., \& Lazăr, L. (2018). Motivations and Preferences of Tourism Consumers Depending on Their Demographic Characteristics. Volumul conferinței "Turismul rural românesc în context internațional. Actualitate și perspective”, 44, 57-62.

OECD, Measuring Entrepreneurship. A Collection of Indicators, OECD-Eurostat Entrepreneurship Indicators Programme,2009, p.6

Park, D., \& Yoon, Y. (2009). Segmentation by motivation in rural tourism: A Korean case study. Tourism Management, 30, 99-108.

Pelau, C., \& Chinie, A. (2018). Clusters Of Tourism Consumers In Romania. Studia Universitatis Vasile Goldis, Economic Series, 28(1), 17-34.

Serban, D., Pelau, C., \& Chinie, A. (2017). Calculation of the differences of attitude and behavior of two generations with the Euclidian-metric. Proceedings of the 11th International Conferince on Business Excellence, 241-247.

Shane, S.A., Venkataraman, S., The promise of entrepreneurship as a field of research, Academy of the Management Review, vol.25, nr. 1, 2000, pp.217-226.

Stevenson, H.H., Jarillo, J.C., A paradigm of entrepreneurship: Entrepreneurial management, Strategic Management Journal, vol. 11, Corporate Entrepreneurship, 1990, pp. 17-27.

Tkaczynski, A., Rundle-Thiele, S., \& Beaumont, N. (2009). Segmentation: A tourism stakeholder view. Tourism Management, 30, 169-175.

Turner, R.K., (2005). Sustainable Environmental Economics and Management: Principles and Practice, Redclift M., Sustainability. Critical concepts in the social sciences, Volume II, Routlege, London, pp. 38-68.

World Tourism Organization - Tourism Market Statistics Service, 2003

World Economic Forum, Educating the Next Wave of Entrepreneurs. Unlocking entrepreneurial capabilities to meet the global challenges of the 21st Century, Geneva, 2009, p.25.

\section{Web Resources}

https://ec.europa.eu/info/sites/info/files/communication-commission- tourism-transport-2020-andbeyond_ro.pdf

https://www.romaniatravel.com/

https://ec.europa.eu/info/sites/info/files/communication-commission-tourism-transport-2020-and-

beyond_ro.pdf 